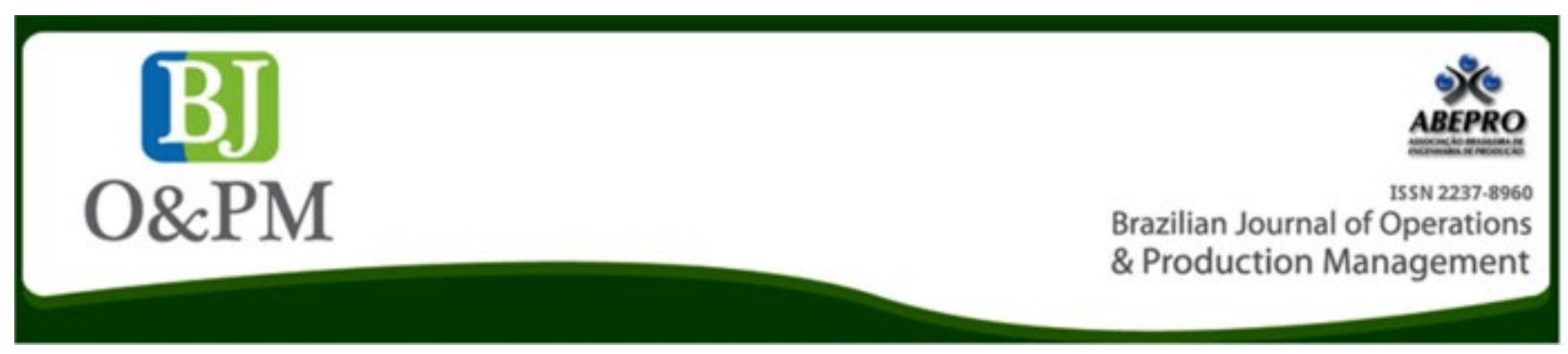

\title{
DEVELOPMENT OF A SCENARIO PROSPECTING MODEL WITH THE USE OF MULTICRITERIA DECISION AIDING: IMPORTANCE OF ENVIRONMENTAL VARIABLES
}

\author{
José Artur Moraes Vieira ${ }^{1}$, Igor Engel Braga ${ }^{1}$, Carlos Francisco Simões Gomes ${ }^{1}$ \\ 1 Department of Production Engineering, Fluminense Federal University
}

\begin{abstract}
The significance of using resources optimally comes from its increasingly present scarcity, whether they are related to the environment, term, financial resources, and political or legal difficulties. This study proposes the use of prospective scenarios, considering multiple and uncertain alternatives. It can be an essential tool for the strategic planning process of organizations. The motivation of the subject studied is the possibility to contribute to the expansion of the corporate strategic planning vision and towards social welfare, related to the commitment of companies to society, since it proposes a model for prospecting scenarios supported by multicriteria decision aiding (MDA) approach, necessarily considering variables related to Corporate Social Responsibility and its nuances. As a result, it is expected to fill the identified gap, which places prospecting scenarios as an empirical tool that deals only with economics and a single future possibility. For further research the application of the model in an actual case is suggested, still raising important questions such as: is there a real contribution with the application of prospective scenarios? Is this tool applicable to any type of company? Who are the stakeholders and how do you measure the effectiveness of this tool?
\end{abstract}

Keywords: Prospective scenarios; Strategic planning; MDA; Corporate Social Responsibility; CSR. 


\section{INTRODUCTION}

Sustainability, conceptually, is the ability of companies to meet their present needs without compromising the ability of future generations to meet their own. (Ipiranga et al., 2011).

The days in which only the focus on maximizing profit, based on economic activities supported by whichever implemented chosen strategy was enough for the full success of a capitalist organization in a given market are gone.

The massification of the information provided by the technologies intrinsic to globalization, allowed the population, in this case the final consumer, as well as all citizens involved and influenced by processes and products handled by the central activity of the companies, to see more closely and substantiated the risks and real impacts that those activities generate to their surrounding environment and, more broadly, to the environmental and social balance of the planet.

On the other hand, there is an increase in terms of trading opportunities for companies due to its socially responsible actions, including an increase in terms of their bargaining power with suppliers, who want their brands to be linked with a company recognized as socially responsible for the market (Coutinho, 2001). This type of positioning is related to Corporate Social Responsibility (CSR), which is based on the notion that corporations have an obligation to work for the improvement of social welfare (Frederick, 1994).

Added to this trade off - environmental protection versus economic gain - are the political, social and technological factors and the synergy between them, which make them more complex environments for decision making by managers and require the development of more accurate planning. To assist the development of strategies in complex environments and marked by uncertainty, a possible technique is scenario development (Smith, et. al, 2012).

All these factors and socioeconomic context added to the advances in terms of science and technology revolution has made the monitoring of transformative processes become a difficult task as well as the complexity of defining strategies to ensure the survival of organizations in the competitive environment has further increased. (Oliveira et Forte, 2010).

Thus, the prospect of future scenarios, considering multiple and uncertain alternatives, gains ground and becomes a fundamental tool for the strategic planning process of public, private and third sector (Stuari, 2008).

Still considering the multiple alternatives available and the various selection criteria, such as supporting this pros- pecting tool scenario, we have the Multicriteria Decision Aiding (MDA), which has been developed to support and drive decision-makers in the evaluation and selection of alternative solution (Gomes et Costa, 2013). These problems require weights of more than one aspect due to its inherent complexity (Longaray et al., 2014a) and the use of an MDA method can contribute to the reduction of subjectivity, bias and process arbitrariness (Paula et Mello, 2013).

Therefore, in order to contribute to the expansion of corporate strategic planning vision and social welfare, related to the commitment of companies towards society, this study proposes a model for prospecting scenarios supported by MDA approach, considering variables directly related to Corporate Social Responsibility and its nuances. To this end, the study is divided into five parts: (i) this introduction, where the subject is contextualised, (ii) the methodology used for developing the model, (iii) the theoretical framework, in which the model being proposed will be grounded through research in literature, (iv) the model is proposed and finally (v) the closing remarks.

\section{METHODOLOGY}

The theoretical framework is based on literature, with important periodicals databases available such as Web of Science, SciELO and SCOPUS, about the importance of prospecting scenarios for corporate strategic planning, the concepts of multicriteria analysis and the influence Corporate Social Responsibility for organizations in the environment in which they operate.

The study comprises a descriptive and exploratory research in order to propose a tool to assist decision-makers/ managers over the strategic planning development process, from the analysis of several criteria that influence the organization, necessarily passing through a Corporate Social Responsibility approach. From the above concepts, in Figure 1 , it is proposed a theoretical and methodological model for structuring the study.

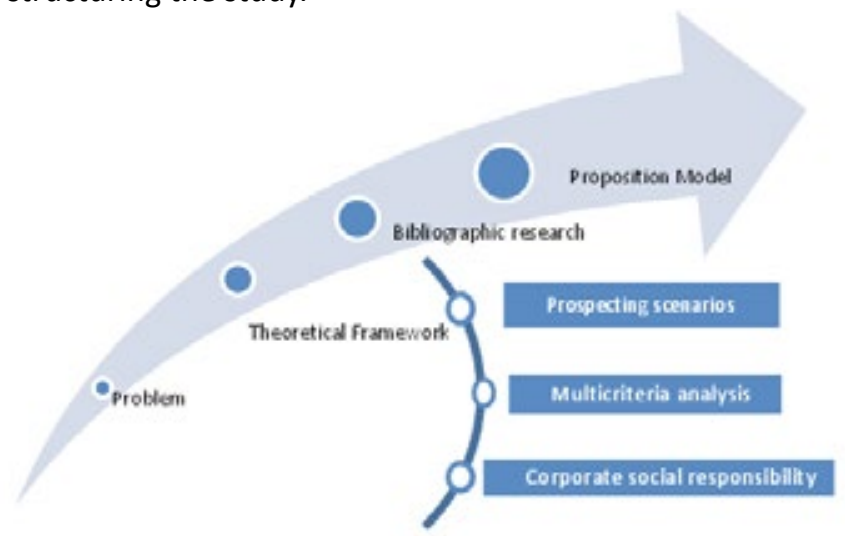

Figure 1 - Methodological framework of the study Source: Authors 


\section{THEORETICAL FRAMEWORK}

\subsection{Prospective Scenarios and Strategic Planning}

Prospecting the future is one of the oldest and most intriguing human needs. One that anticipates the trends and acts proactively has much better chances of success than competitors (Sturari, 2008).

The scenario building studies have been widely used in large enterprises management, both in Brazil and abroad. This instrument becomes indispensable for "offering an alternative future benchmark according to decisions that will be taken" (Buarque, 2003, p. 7). Wright et Spers (2006) argue that developing scenarios is not a prediction exercise, but rather an effort to make plausible and consistent descriptions of possible future situations, presenting the conditioning of each way between the current situation and the future scenarios, highlighting the relevant factors to decisions that need to be taken. Therefore, the prospecting of future scenarios, considering multiple and uncertain alternatives, gains ground and becomes a fundamental tool for the strategic planning process of public, private and third sector (Sturari, 2008).

From a technical and applied point of view, several methodologies can be identified to assist in the development of scenarios and integrate them into strategic decision making, as in Gomes' works, Gomes (2012), Van der Heijden (2009), Wright et Spers (2006), Schwartz (2006), Godet (1996, 2000a), Global Business Network (GBN) (1998), Schoemaker (1995), Mason (1994) and Hoton (1987). Each with its peculiarities in regard to nomenclatures, attributes and order of steps to be followed during construction (Gomes, 2014).

However, from an academic and scientific point of view it is necessary to investigate the development and use of scenarios as an organizational phenomenon that may have direct implications in the strategist's performance and strategy itself, and therefore in the the organization performance (Smith, et. al., 2012).

Table 1 lists up the particular characteristics of different methodological approaches for building scenarios studied by Bonaventure, Fischmann et Costa (2005) and supplemented by the authors of this work:
Table 1. Methods and steps for prospective scenarios formulation.

\begin{tabular}{|c|c|}
\hline METHODS & STEPS \\
\hline $\begin{array}{l}\text { SRI Interna- } \\
\text { tional (Stan- } \\
\text { ford Research } \\
\text { Institute) }\end{array}$ & $\begin{array}{l}\text { 1. Define the strategic decisions that the scenar- } \\
\text { ios should address; } \\
\text { 2. Identify the key-factors of decision; } \\
\text { 3. Analyse environmental forces; } \\
\text { 4. Develop logical scenarios; } \\
\text { 5. Scenarios description; } \\
\text { 6. Identify strategic implications for decision } \\
\text { making. }\end{array}$ \\
\hline $\begin{array}{c}\text { Global Busi- } \\
\text { ness Network }\end{array}$ & $\begin{array}{l}\text { 1. Identify the issue or central decision; } \\
\text { 2. Identify the key-factors in local environment; } \\
\text { 3. Identify the macro-environment driving } \\
\text { forces; } \\
\text { 4. Rank the key factors by importance and } \\
\text { uncertainty; } \\
\text { 5. Select the scenarios logic; } \\
\text { 6. Scenarios drafting; } \\
\text { 7. Analyse the implications; } \\
\text { 8. Select early indicators and warning signs for } \\
\text { future monitoring. }\end{array}$ \\
\hline $\begin{array}{l}\text { Future Map- } \\
\text { ping }\end{array}$ & $\begin{array}{l}\text { 1. Create the final stages and events; } \\
\text { 2. Explicit the current mental model - conven- } \\
\text { tional wisdom scenarios; } \\
\text { 3. Map the final stages; Participants are divided } \\
\text { into groups; } \\
\text { group; } \\
\text { 4. Build the scenarios for presentation to the } \\
\text { 5. Analyse the common and divergent points for } \\
\text { the scenarios; } \\
\text { 6. Select the most desirable final state; } \\
\text { 7. Map the strategic direction. }\end{array}$ \\
\hline
\end{tabular}

1. Define the structure of the subject to be searched;

2. Identify and structure areas of influence on the subject;

3. Define the descriptors, with the logic for each one and assign initial probabilities of occurrence to each state of them;

Battelle Memorial Institute

4. Fill the Cross Impact Matrix with the odds identified in step 3 and run the BASICS program;

5. Select scenarios for further study and elaborate their narrative;

6. Introduce low probability events, but with high impact, and conduct the sensitivity analysis in order to analyze its effects;

7. Develop projections arising from scenarios and assess their implications for the company.

1. Analyse the problem and delimt the system;

2. Diagnosis of the company; 3. Structural analysis;

Prospective Analysis
4. Enterprise dynamics in the environment;

5. Environmental scenarios;

6. Identify strategies;

7. Evaluate strategies;

8. Select strategies;

9. Develop action plans and monitor strategy. 


\begin{tabular}{cc}
\hline & $\begin{array}{c}\text { 1. Divergent phase: the individual view of each } \\
\text { decision maker regarding the nature and struc- } \\
\text { ture of the strategic situation is diagrammed } \\
\text { separately, without the influence of ideas by } \\
\text { other participants in the process; } \\
\begin{array}{c}\text { sive Situation } \\
\text { Mapping }\end{array}\end{array} \quad \begin{array}{c}\text { 2. Convergent phase: process participants inter- } \\
\text { act in a debate with presentations of diagrams } \\
\text { developed individually; analysis of more and } \\
\text { less important hypotheses and a possible con- } \\
\text { solidation of ideas. }\end{array}$ \\
$\begin{array}{c}\text { 1. Preparation: a) focus setting - issues that } \\
\text { need to be answered to define the limits of } \\
\text { the scenarios to be created; b) mapping of the } \\
\text { driving forces that are better able to shape the } \\
\text { future of the industry. }\end{array}$ \\
$\begin{array}{c}\text { 2. Development: a) construction of the scenery } \\
\text { space with classification of various future states } \\
\text { as a function of the driving forces; b) selection } \\
\text { of scenarios to be detailed; c) detailing of the } \\
\text { scenarios, relating trends and the events re- } \\
\text { quired to reach each of the final states. } \\
\text { Analysis } \\
\text { 3. Documentation and use: a) documentation, } \\
\text { including pictures and narratives that describe } \\
\text { the history represented in each scenario; b) } \\
\text { evidence of the implications of each scenario - } \\
\text { how different the decisions about business will } \\
\text { be according to each type of scenario. }\end{array}$ \\
\hline
\end{tabular}

1. Define the scope and time frame 2. Identifiy the stakeholders.

3. Identify basic trends

Decision Strategies International

4. Identify the key-uncertainties

5. Build initial scenarios themes;

6. Check the consistency and plausibility

7. Develop learning scenarios

8. Identify additional research needs

9. Develop quantitative models

10. Develop decision scenarios.

1. Define the system in a precise way;

2. Analysis, description and identification of parameters;

Morfologic

Analysis

3. Evaluate parameters and define their states (situations that can be assumed);

4. Include restrictions in order to eliminate inconsistent combinations;

5. Combine alternatives between the states of each parameter considering its restrictions.

1. Define the problem;

2. Identify the variables;

Scenarios Method
3. Retrospective analysis of variables;

4. Define the actors' strategic objectives; 5. Scenarios projection
1. Define the main question and the analysis period;

2. Identify the key-indicators;

Interax Meth- 3. Projections of the key-indicators; od 4. Probability distribution of the event; 5. Estimate the impacts of events over trends; 6. Cross-impact matrix; 7. Develop the scenarios.

1. System Definition (company), inputs and outputs (expected results);

2. Identify the Mission and Vision for the Future; 3. Uncertainties and their causative factors;

4. Identify the internal variables (strengths and weaknesses) and external ones (opportunities and threats);

5. Identify variables relevant to the prospective analysis and study them (likelihood of occur-
Unified

Method of

Prospective

Strategy Planning (SWOT)

Integration between MDA and Prospect-

ing rence, retrospective analysis);

6. Identify the key-indicators and make their retrospective analysis;

7. Identify the striking effects and assign prob-

abilities to them - Cross-impact matrix (striking effect versus indicators);

8. Identify the scenarios (most likely, optimistic and pessimistic);

9. Build the impact matrix between the components of scenarios and verify if the occurrence

of a component influences the other;

10. Search for competitive advantages and disadvantages in each scenario;

11. Position the company in each scenario.

1. Problem characterization;

2. Identification of alternatives;

3. Scenarios prospecting and criteria identification;

4. Estimate weight of each criterion for each scenario:

5. Evaluate performance of each alternative for each criterion;

6. Use of aggregation algorithm, determining

the usefulness of each alternative in each scenario;

7. Rank the alternatives in each scenario; 8. Identify the robustness of solutions.

Godet (2000b) states that, in practice, there is no single method for developing scenarios, but a variety of methods for the construction, some being simplistic and other sophisticated. However, the actor points out that systems analysis retrospective, actors' strategy and scenarios development would be intrinsic steps to the scenario construction process.

When the organization starts to plan through prospecting scenarios, this is a step forward to their management and decision-making maturity, as uncertainties are taken into account when building the future (Ribeiro, 2006). Scenarios are not predictions about what will happen, but descrip- 
Brazilian Journal of Operations \& Production Management

Volume 14, Número 1, 2017, pp. 210-217

DOI: 10.14488/BJOPM.2017.v14.n2.a9 tions, based on plausible assumptions of what might happen (Gomes Costa, 2013).

In a world of increasing uncertainty, the prospection of scenarios is a way of thinking optimally on a wide range of potential outcomes of variables that can impact the future of an organization (Carvalho, 2009).

\subsection{Multicriteria decision aiding - The AHP method}

In many real situations of decision-making, several possible solutions may be considered, which requires decision makers to take into account different points of view. This fact corroborated the emergence of a tool that could support them in their decisions. This approach, entitled MDA, has some advantages that are worth mentioning: (i) create a basis for dialogue between analysts and decision makers; (ii) ease of incorporating uncertainty in several points of view, or (iii) possible to foresee every alternative conflict from different points of view (Pinto Junior et Soares de Mello, 2013).

Due to the complexity of a decision process with several criteria and alternatives, pondering on more than one aspect is necessary (Longaray et al., 2014) (Longaray et Ensslin, 2014b). In this research, we opted for the AHP method (Analytic Hierarchy Process) for its broad applicability, robustness and flexibility (HO, 2008).

The AHP is the most widely used multicriteria method for planning and management in the oil and gas industry (Gomes et al., 2010), considered by many to be a complex environment; as well as strategic planning, since it includes several variables, especially in this study for the socio-environmental variable, in terms of corporate social responsibility. This predominance of AHP applications in support of multicriteria decision was also observed in other studies as in: (Ho et al., 2010), (Wu et Barnes, 2011) and (Mexas et al., 2012).

Proposed by Thomas Saaty (1991), AHP is modeled on a descending hierarchical structure starting from a primary objective, passing to criteria, then subciteria, and finally the alternatives, in successive levels. Thus, the objective is the first level, which is broken down into criteria, which can be subdivided into sub-criteria, until it meets the identification of the problem as completely as possible without losing sensitivity to changes. At last, the decision alternatives.

The criteria judgment is made by comparing pair by pair, using a scale (Figure 2) developed by Saaty (1990) and arranged as a comparison matrix such as shown in Figure 3.
Pair-wise Comparison Scale for AHP preference.

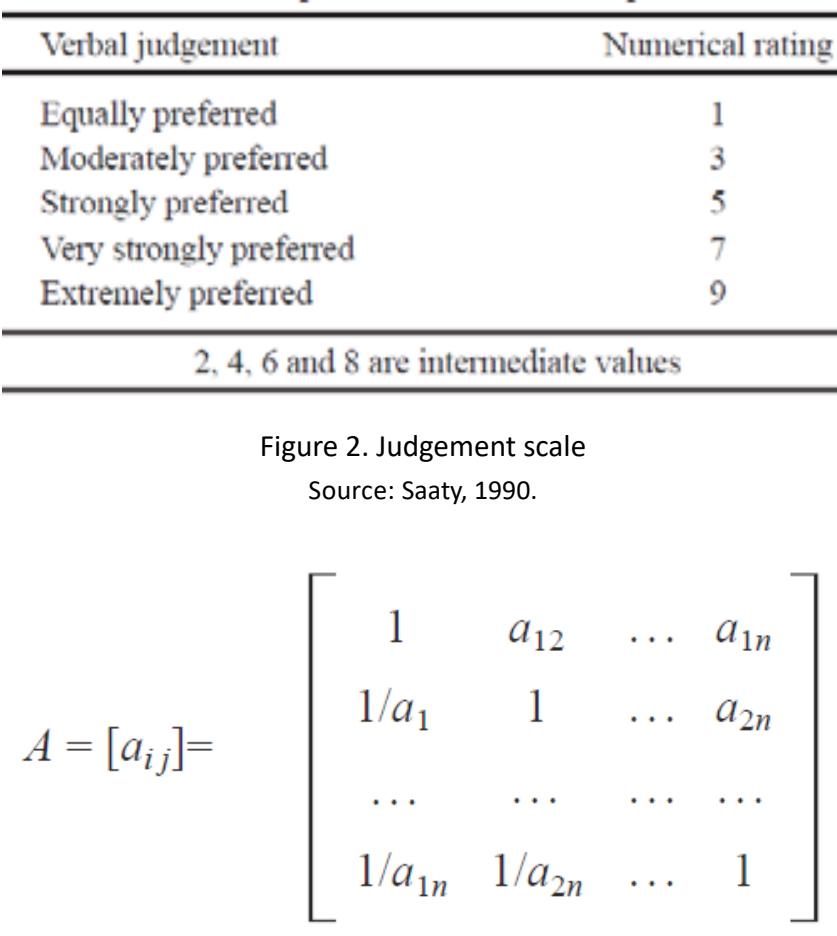

Figure 3. Generic reciprocal matrix Source: Longray, 2014.

Then, for each set of criteria, comparison matrices are used to obtain the relative priorities of each criterion. Priorities should be numbers between 0 and 1 , and their sum must be 1 (Colin, 2007).

In the next step, the consistency of judgments made by the decision maker is evaluated (Longaray; Bucco, 2014b). For that, it is necessary to calculate the Consistency Ratio of judgments, denoted $\mathrm{CR}=\mathrm{Cl} / \mathrm{RI}$, where RI is the Random Consistency Index obtained for a reciprocal matrix of order $\mathrm{n}$ with non-negative and randomly generated elements. The Consistency Index $(\mathrm{Cl})$ is given by $\mathrm{Cl}=(\lambda \max$ -n) / (n-1) where $\lambda$ max is the largest eigenvalue of the judgment matrix. According to Saaty (2000), the consistency condition of judgements is $C R \leq 0.10$. (Trevizano et al., 2005) (Marins et al., 2009).

\subsection{Corporate Social Resposability}

Corporate Social Responsibility (CSR) was a term launched by $\mathrm{H}$. Bowen, who wrote "Social Responsibility of Businessmen" in 1953. His main idea was to describe and take into account the integration of social and environmental issues in corporate decisions, goals and operations. 
Caroll (1979) was one of the first who addressed the concept of Corporate Social Performance (CSP), which later Ullman (1985), on top of his concepts, proposed a generic model to obtain it. Later on, Wood (1991) stated that the basic idea of CSR is to believe that business and society are intertwined. Thus, the company develops expectations in terms of how entrepreneurs behave and act.

In this context, strategic approaches that include the social dimension in the scope of planning has achieved undeniable relevance. One approach still considered one of the most traditionally adopted in corporate strategic planning environment is the concept presented by John Elkington in 1999 in merging the economic, social and environmental dimensions aimed at achieving the so-called corporate sustainability. This model was named Triple Bottom Line or Tripod Sustainability, Figure 4.

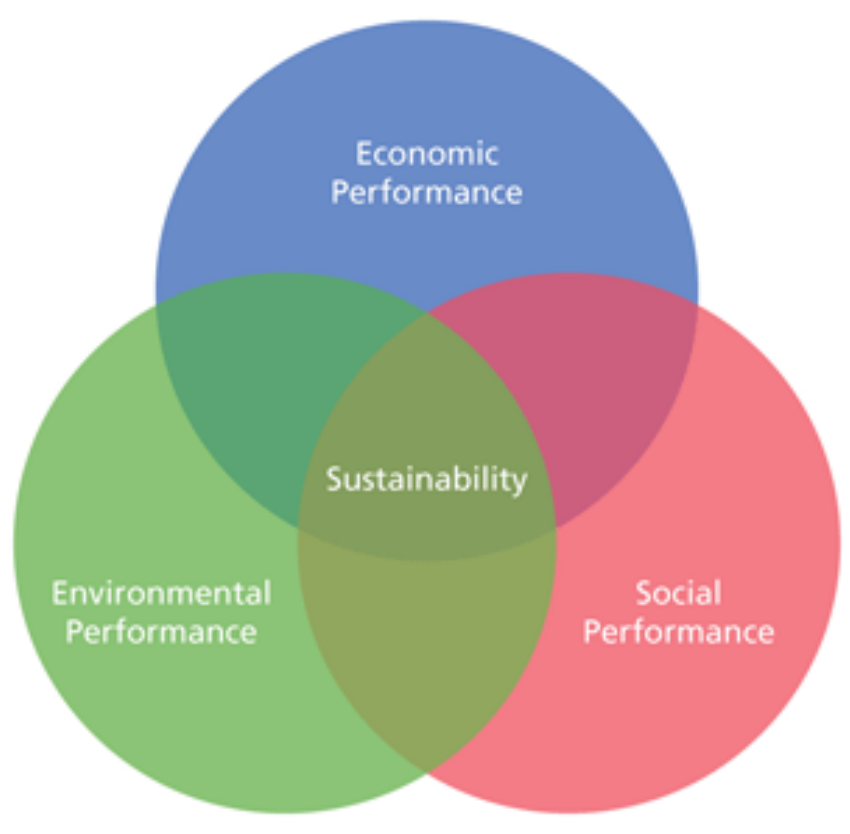

Figura 4. Triple Bottom Line approach structure

Source: Projeto Educação para Sustentabilidade, coordinated by NEATS from PUC-SP

Over the years, more and more works address the issue of social responsibility, as you can see in Scopus scientific base, with annual publications on the term "corporate social responsibility" more than quadrupling, from 256 publications, in 2005, to 1.260 in 2015 (Figure 5).

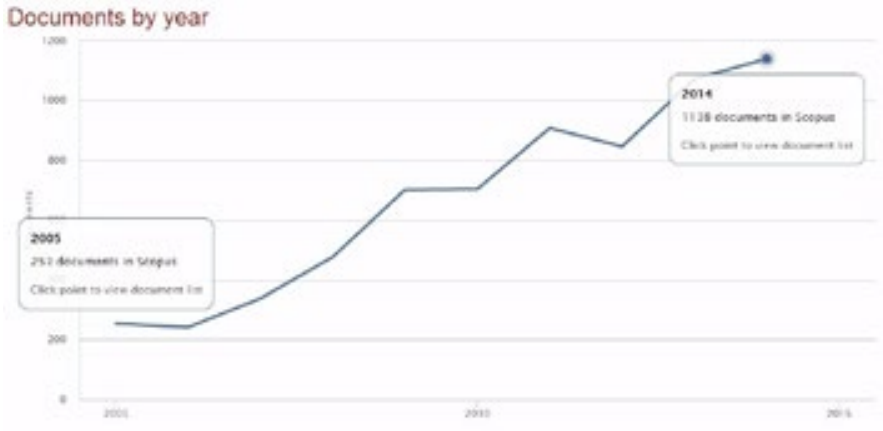

Figure 5 - Publications in Scopus scientific base, year by year (2005-2015), about the "corporate social resposibility" theme.

Source: Graphic automatically generated on Scopus platform, in 25/02/2015.

Among recent works, Morel et. al. (2015) had findings that show that internal social responsibility has remarkable influence on the affective organizational commitment of employees. Lai, et. al. (2015), besides observing the large number of works that relate corporate social responsibility with marketing strategies, realize how much it affect the organization performance positively when worked along with the brand management and its value as an intangible asset. This way the company's value can be maximized through an adequate management of these two issues.

In this sense, CSR is revealed as an essential activity during the drafting process of the strategic planning of organizations nowadays.

\section{MODEL PROPOSITION}

Having the theoretical framework as an outline, this section includes a proposal of integration between prospecting scenarios and multicriteria decision analysis, specifically the use of AHP technique.

Figure 6 shows the model in a clear and objective manner, to facilitate the reader's understanding in terms of the steps proposed, namely:

1. System Definition; for this study, the system must be considered as the organization being studied. At this stage, the entries (inputs), the expected results, the internal variables (strengths and weaknesses) and the external variables (threats and opportunities) at the present moment (current month and year) were identified. At this stage, the uncertainties and important stackholders were also defined.

2. Problem Definition; it refers to a future problem, or a need for planning for any specific situation or even the Strategic Planning itself. 
3. Identification of criteria and sub-criteria that impact the system; at this stage, the sub-criteria of each identified criterion should be exhausted. When it comes to organizational strategic planning, one must necessarily consider criteria of political, social, technological, economic, environmental and legal matter.

4. Prioritization of sub-criteria; by AHP, a multi-criteria decision aiding tool, the sub-criteria should be standardized so that we can identify the most relevant from the point of view of the different stakeholders.

5. Identification and classification of variables (sub-criteria); after getting to know the most important sub-criteria within each set of criteria a cross-impact matrix is drawn up in order to identify the ones that cause more impact and those most impacted, assigning weights to them.

6. Scenarios Construction; after the steps 4 and 5 were completed, we have the most relevant subcriteria that should be planned through qualitative and quantitative assessments. From these, four scenarios are built - Probable, Optimistic, Pessimistic and Disruptive.

7. Preparation of Strategic Planning; with the completion of step 6, composed by the variation of the alternatives within each scenario, the expected return for the manager should be chosen through techniques of decision theory, obtaining finally the scenario that should be prioritized for the preparation of Strategic Planning.

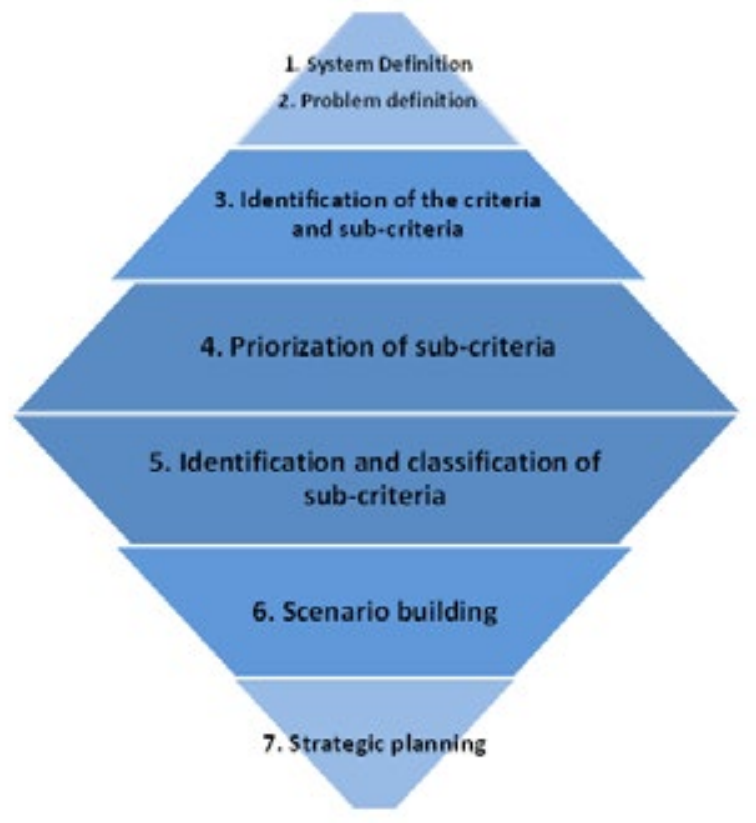

Figura 6. Proposed Model Source: Authors

\section{FINAL CONSIDERATIONS}

Awareness in terms of the possible future scenarios allows decision-makers and stakeholders to be better prepared, at the present time, for the definition of strategies and for dealing with uncertainties in this changing environment (Wright et Spers, 2006; Schwartz, 2006; Silva et al. 2012). The preparation of the future strategy involves the decision in terms of how the organization intends to relate to the external environment, considering the capture of opportunities and the facing of identified threats in this external environment given the horizon for planning (Silva et al., 2012).

The theoretical model proposed here is intended to equip an essential activity for the survival of the business, the Strategic Planning, which have empirical features, since it depends on the experience and interest of the main stakeholders. With the multicriteria decision aidding, added to decision theory techniques, it is possible to minimize such bias, since it has scientific methods to do so.

Another major contribution of this study is related to the importance given to corporate social responsibility issues, a subject-matter that, over the years, has been lauching an increasingly number of works, more than quadrupling over the last 10 years, as discussed in theoretical framework. In other words, this criterion cannot be overlooked by decision-makers, since it can be taken as competitive advantage or, ultimately, it can lead the organization to track the global trends.

As a gap in this research is the application of the model in an actual case, even raising important questions such as: Is there real contribution to the application of prospecting scenarios? Is this tool applicable to any type of company? Who are the stakeholders and how do you measure the effectiveness of this tool?

\section{REFERENCES}

Buarque, S. C. (2003) Metodologia e Técnicas de Construção de Cenários Globais e Regionais. Elaborado por empresas e instituições nacionais e regionais no Brasil.

Carvalho, D. E. (2009). Future Studies. Research Journal. São Paulo, v. 1, n. 1, pp. 02-27, Jan./Jun.

Colin, E. C. (2007) Pesquisa operacional: 170 aplicações em estratégia, finanças, logística, produção, marketing e vendas. 1 . ed. Rio de Janeiro: LTC.

Coutinho, R. B. G. (2001). Responsabilidade social corporativa no Brasil: o caso da DPaschoal Automotiva. Em: Dissertação (Mestrado em Administração) - Instituto de Administração e Gerência, Pontifícia Universidade Católica do Rio de Janeiro.

Frederick, W. C. (1994) From CSR1 to CSR2. Em: Business and Society, v. 33, n. 2, p.150-164. 
Godet, M. A. (2000a). The art of scenarios and strategic planning: tools and pitfalls. Technological Forecasting and Social Change. V. 65, n. 1, set. 2000. p. 3-22.

Godet, M. A., (2000b). How to be Rigorous with Scenarios Plannig, Paris, Futuribles - January

Godet, M. A. (1996). Creating the Future: The use and misuse of scenarios, Long Range Planning, Vol29 - No. 2, pp.164-177.

Gomes, C. F. S., Costa, H. G. (2013), Proposta do uso da visão prospectiva no processo multicritério de decisão. Relatóriso de Pesquisa em Engenharia de Produção. v.13, n.8, pp. 94-114

Gomes, C.F.S., Gomes, L.F.A.M., Maranhão, F.J.C. (2010) Decision analysis for the exploration of gas reserves: merging todim and thor. Pesqui. Oper. 30, 601-617. doi:10.1590/S010174382010000300006

Global Business Network(GBN) (1998). Scenarios Trainning Manual.

Ho, W., Xu, X., Dey, P.K. (2010) Multi-criteria decision making approaches for supplier evaluation and selection: A literature review. Eur. J. Oper. Res. 202, 16-24. doi:10.1016/j. ejor.2009.05.009

Ho, W. (2008) Integrated analytic hierarchy process and its applications - a literature review. European Journal of Operational Research, v. 186, n. 1, p. 211-228, 2008.

Ipiranga, A.S.R., Godoy, A.S., Brunstein, J. (2011) Introdução. RAM Rev. Adm. Mackenzie Online 12, 13-20. doi:10.1590/ S1678-69712011000300002

Lai, C.S., Chiu, C.J., Yang, C.F, Pai, D.C. (2015) The effects of corporate social responsibility on brand equity and firm performance. Journal of Business Research 68 2232-2236 - DOI 10.1007/s10551-010-0433-1

Longaray, A., Bicho, M., Ensslin, L., (2014a) Utilização da MCDA para Avaliar os Critérios do Programa de Excelência: Um Estudo de Caso em uma Agência Marítima. Sist. Gest. 9, 258274. doi:10.7177/sg.2014.v9.n3.a4

Longaray, A., Bucco, G. B. (2014b) Uso da Análise de Decisão Multicritério em processos licitatórios públicos: Um estudo de Caso. Revista Produção Online, Florianópolis, SC, v.14, n. 1, p. 219-241, jan./mar. 2014.

Marins, C. S., Souza, D. O., Barros, M. S. (2009) O uso do método de Análise Hierárquica (AHP) na tomada de decisões gerenciais - Um estudo de caso. XLI SBPO 2009 - Pesquisa Operacional na Gestão do Conhecimento

Mason, D. H. (1994). Scenario-based planning: decision model for the learning organization, Planning Review, vo1.22,mar/ apr,1994. p6-11.

Mexas, M.P., Quelhas, O.L.G., Costa, H.G. (2012). Prioritization of enterprise resource planning systems criteria: Focusing on construction industry. Int. J. Prod. Econ. 139, 340-350. doi:10.1016/j.ijpe.2012.05.025
Oliveira, V. O.; Forte, S. H. A. C. (2010) O uso de cenários prospectivos na formulação da estratégia: uma aplicação na indústria bancária brasileira. Em: VII Convibra Administração - Congresso Virtual Brasileiro de Administração, 19 a 21 de novembro.

Paula, J.O., Mello, C.H.P. (2013) Seleção de um modelo de referência de PDP para uma empresa de autopeças através de um método de auxílio à decisão por múltiplos critérios. Produção 23, 144-156. doi:10.1590/S0103-65132012005000082

Pinto Junior, R.P. da S., Soares de Mello, J.C.C.B. (2013) Identificação da melhor escolha de funcionário para realização de inspeção em estatais do setor elétrico. Produção 23, 135-143. doi:10.1590/S0103-65132012005000041

Ribeiro, M. P. M. (2006). Planejamento por cenários: uma ferramenta para a era do conhecimento. Revista Intersaberes | vol.1 n. 1, p. 186 - 202 | jan-jun.

Saaty, T. (1990) How to make a decision: The analytic hierarchy process. European Journal of Operational Research, v. 48, 9-26.

Saaty, T. (1991) Método de análise hierárquica. São Paulo: Makron Books.

Silva, A. T. B.; Spers, R. G.; Wright, J. T. C. (2012) The Development of Scenarios in Strategic Management of Organizations: a literature study. Em: Revista de Ciências da Administração, V. 14, n. 32, p. 21-34.

Schwartz, P. A. (2006) Arte da Visão de Longo Prazo. Planejando o futuro em um mundo de incertezas, 4. ed. Rio de Janeiro: Best Seller, 2006. 213 p.

Schoemaker, P. J. H. (1995). Scenario planning: a tool for strategic thinking. Sloan Management Review. 36 (2). p25-40.

Sturari, R. (2008) Metodologia de descrição de cenários. SAGRES - Política e Gestão Estratégica Aplicadas.

Trevizano, W. A.; Freitas, A. L. P. (2005) Emprego do Metodo da Analise Hierarquica (A.H.P.) na selecao de Processadores. In: XXV Encontro Nac. de Engenharia de Producao - Porto Alegre, RS, Brasil, 29 out a 01 de nov. de 2005.

Ullman, A. (1985). Data in search of a theory: A critical examination of the relationships among social performance, social disclosure, and economic performance. Academy of Management Review, 10: 540-577.

Van der Heijden, K. (2009), Planejamento por cenários: arte da conversação estratégica. 2. ed. Porto Alegre: Bookman.

Wood, D. J. (1991) Corporate Social Performance Revisited. The Academy of Management Review Vol. 16, No. 4 pp. 691-718

Wright, J. T. C., Spers, R. G. (2006) O país no futuro: aspectos metodológicos e cenários. Estudos Avançados, 20(56), 13-28, 2006.

Wu, C., Barnes, D. (2011) A literature review of decision-making models and approaches for partner selection in agile supply chains. J. Purch. Supply Manag. 17, 256-274. doi:10.1016/j.pursup.2011.09.002 